OPEN

SUBJECT AREAS:

CLIMATE AND EARTH

SYSTEM MODELLING

VOLCANOLOGY

PETROLOGY

GEOCHEMISTRY

Received

4 March 2014

Accepted

22 July 2014

Published

18 August 2014

Correspondence and requests for materials should be addressed to A.R. (anja.rosenthal@ uni-bayreuth.de)

* These authors contributed equally to this work.

\section{Continuous eclogite melting and variable refertilisation in upwelling heterogeneous mantle}

\author{
Anja Rosenthal ${ }^{1,2}$, Gregory M. Yaxley' , David H. Green 1,3, Joerg Hermann ${ }^{1 *}$, István Kovács ${ }^{1,4 *}$ \\ \& Carl Spandler ${ }^{5 *}$
}

${ }^{1}$ Research School of Earth Sciences, The Australian National University, Canberra, Mills Road, ACT 0200, Australia, ${ }^{2}$ Bayerisches Geoinstitut, University of Bayreuth, 95440 Bayreuth, Germany, ${ }^{3}$ School of Earth Sciences and Centre for Ore Deposit Studies, University of Tasmania, Hobart 7001, Tasmania, Australia, ${ }^{4}$ Geochemical and Laboratory Department, Geological and Geophysical Institute of Hungary, Budapest, Stefánia Street 14, H-1 143, Hungary, ${ }^{5}$ School of Earth and Environmental Sciences, James Cook University, Townsville, Australia.

Large-scale tectonic processes introduce a range of crustal lithologies into the Earth's mantle. These lithologies have been implicated as sources of compositional heterogeneity in mantle-derived magmas. The model being explored here assumes the presence of widely dispersed fragments of residual eclogite (derived from recycled oceanic crust), stretched and stirred by convection in the mantle. Here we show with an experimental study that these residual eclogites continuously melt during upwelling of such heterogeneous mantle and we characterize the melting reactions and compositional changes in the residue minerals. The chemical exchange between these partial melts and more refractory peridotite leads to a variably metasomatised mantle. Re-melting of these metasomatised peridotite lithologies at given pressures and temperatures results in diverse melt compositions, which may contribute to the observed heterogeneity of oceanic basalt suites. We also show that heterogeneous upwelling mantle is subject to diverse local freezing, hybridization and carbonate-carbon-silicate redox reactions along a mantle adiabat.

- he plate tectonic paradigm suggests that oceanic crust and underlying lithospheric mantle are recycled into the mantle as cool, subducted slabs at convergent margins. During subduction of oceanic lithosphere, basaltic crust reacts to form quartz/coesite eclogite at high pressure and low temperature conditions under which partial melting is avoided or limited to low temperature melting at the wet solidus (that is the temperature at which a silicate melt first appears in a rock in the presence of an aqueous fluid). The breakdown of hydrous phases such as lawsonite and phengite results in the liberation of an aqueous fluid during progressive metamorphism but traces of water can be retained in eclogitic garnet and clinopyroxene that are nominally anhydrous minerals (NAMs) ${ }^{1-5}$. Subducting slabs often descend to the Transition Zone, and in some cases, into the lower mantle $e^{6,7}$. As such slabs are dominated by residual to refractory lithospheric peridotite (depleted lherzolite to harzburgite), their negative buoyancy is reversed if their temperatures approach that of surrounding fertile peridotitic mantle ('fertile' MORB-source mantle or 'modern, well-mixed mantle'). Heterogeneity in the mantle persists when subducted slabs dominated by depleted peridotite with discrete bodies of quartz/coesite eclogite (former oceanic crust) are entrained and mixed into convecting mantle. Later sampling of such mantle domains during partial melting is regarded as essential to the formation of some mantle-derived primitive magmas ${ }^{8-13}$. The model being explored here postulates that subducted slabs heated to approach the intraplate geotherm will undergo localised melting within slab heterogeneities or at slab/fertile mantle interfaces. As temperatures equilibrate, buoyant adiabatic upwelling of heterogeneous peridotite mantle containing discrete bodies of coesite eclogite induces local melting and possible metasomatism of surrounding ambient mantle.

Spandler et al. ${ }^{12}$ presented the melting phase relations of a model composition (GA2) representative of fertile oceanic crust over a decompression path from $\sim 160 \mathrm{~km}$ (5 GPa). A composition (Res2) of the residue after extraction from $\mathrm{GA} 2^{2}$ of $\sim 15 \%$ potassic dacitic-rhyodacitic melt at $5 \mathrm{GPa}$ forms the basis of our experimental study. It is a 'dry' (nominally anhydrous) coesite eclogite (Supplementary Fig. (SFig.) 1; Supplementary Table (STable) 1). In our experiments we investigated further temperature rise at $5 \mathrm{GPa}$ with consequent melting of Res2. We also crystallised Res2 under conditions simulating further decompression melting from $\sim 160$ to 


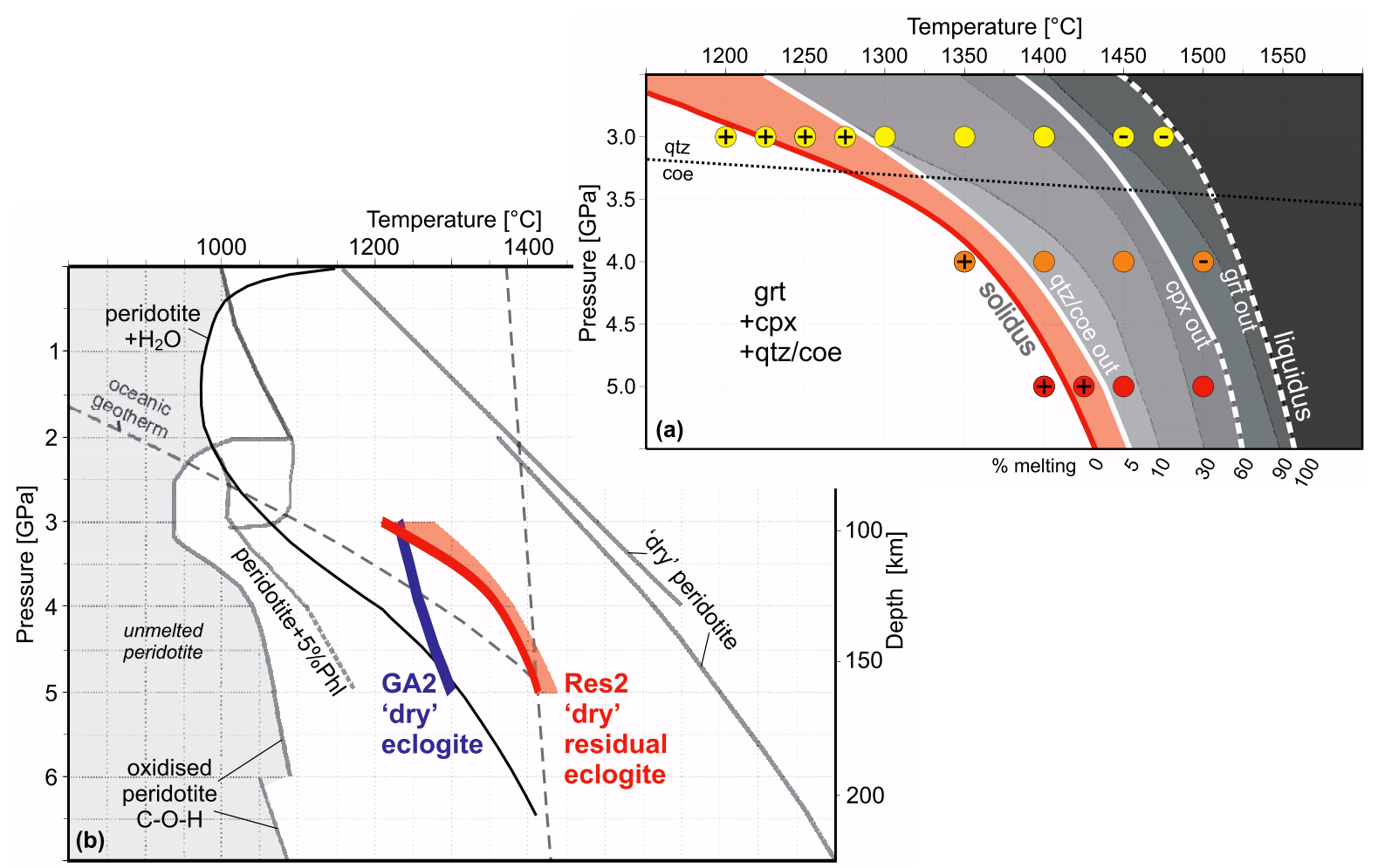

Figure $1 \mid$ (a) Pressure-Temperature-grid of experimentally-determined melting and phase relations of Res2. (b) Comparison of Res2 solidus surface and its (incipient) melting regime with solidii of other experimentally determined mantle lithologies. (a) See explanations within text. Yellow circles - Res 2 at $3 \mathrm{GPa}$, orange circles - Res 2 at $4 \mathrm{GPa}$, red circles - Res 2 at $5 \mathrm{GPa}$. The symbols ' + ' and '-' indicate the presence of quartz/coesite and absence of clinopyroxene, respectively, as residual phases. Solid and dashed white lines are determined and inferred phase boundaries, respectively. The quartzcoesite transition is taken from Bose \& Ganguly ${ }^{44}$; qtz, quartz; coe, coesite; grt, garnet; cpx, clinopyroxene. (b) The Res2 solidus lies between the 'dry' lherzolite solidus ${ }^{29,45}$, and GA2 eclogite ${ }^{12}$ and volatile-bearing lherzolite (i.e. peridotite $+\mathrm{H}_{2} \mathrm{O} \pm \mathrm{CO}_{2}$ ) solidus ${ }^{26,29,30-32}$. The light red shaded area adjacent to Res 2 solidus is the incipient melting regime with garnet + clinopyroxene + quartz/coesite residue. Predicted mantle $\mathrm{T}_{\mathrm{p}}$ 's range from $1280-1600^{\circ} \mathrm{C}^{46-48}$ but for illustrative purposes, we chose a mantle adiabat of $\mathrm{T}_{\mathrm{p}} \approx 1360^{\circ} \mathrm{C}$ so that the solidus of Res 2 intersects the adiabat at $5 \mathrm{GPa}$ at $\sim 1410^{\circ} \mathrm{C}$, initiating melting. Using other adiabats will simply shift the pressure of the onset of melting of various lithologies by $\sim 1 \mathrm{GPa}$ per $100^{\circ} \mathrm{C}^{12}$. Although such changes would not alter the principles of the scenarios ${ }^{12}$, they would substantially influence the composition of melts and solid residues of mantle lithologies at the onset of melting, and thus, would also influence any associated mantle metasomatism.

$\sim 90 \mathrm{~km}$ depth (5 to $3 \mathrm{GPa}$ ) to examine melts and residues along an upwelling path (STable 2). Our guiding concept is that these local eclogite-derived melts migrate into, and react with, enclosing peridotite/harzburgite.

Results of Res2 phase and melting relations at 3-5 GPa, 1200$1500^{\circ} \mathrm{C}$ are presented in Figs. 1-3, and in the supplementary items (Supplementary Notes (SNotes), SFigs. 1-11, and STables 1-4). The initial aim of this research was to perform experiments under anhydrous conditions. However, analyses of glasses from quenched melts in several runs, especially in those with low melt fractions, often returned very low totals (down to $92.3 \mathrm{wt} . \%$; STable 3), indicative of the possible presence of a volatile component in the quenched liquid. Therefore, experiment Res2_19 containing 99\% melt was subject to quantitative Fourier-transform infrared spectroscopy (FTIR) analysis, and $\sim 0.27 \mathrm{wt} \% \mathrm{H}_{2} \mathrm{O}$ was detected (SFig. 2; STable 4). Hence, the Res2 starting composition is expected to contain $\sim 0.26$ wt. $\%$ of $\mathrm{H}_{2} \mathrm{O}$. This water content is of the order that may be contained in nominally anhydrous ('dry') residual eclogite ${ }^{2}$, but its presence demonstrates that hydrogen could not be entirely eliminated from the experiments and must be considered during interpretation of the results, as the presence of water may lower solidus temperatures relative to truly anhydrous runs. Subsolidus phases for Res2 are garnet, omphacitic clinopyroxene and quartz/coesite (Fig. 1a; SFigs. 3 \& 4; STables 2 \& 3; SNotes). The Res2 solidus is located at $1210 \pm$ $15^{\circ} \mathrm{C}$ at $3 \mathrm{GPa}, 1375 \pm 25^{\circ} \mathrm{C}$ at $4 \mathrm{GPa}$, and $1410 \pm 15^{\circ} \mathrm{C}$ at $5 \mathrm{GPa}$ (Fig. 1; STable 2). At very low degree (incipient) melting, liquids appeared mainly at triple grain boundaries as tiny $(\leq 5 \mu \mathrm{m})$, partly connected pools of quenched glass in assemblages where quartz/coesite is present (SFig. 3; STable 2). As in previous studies ${ }^{12-15}$, quartz $(\leq 3.0 \%$ at $3 \mathrm{GPa})$ or coesite $(<1 \%$ at $5 \mathrm{GPa})$ is a residual phase in association with a eutectic-like incipient $(\leq 5 \%)$, dacitic and sodic melt near the solidus over a temperature interval of up to $100^{\circ} \mathrm{C}$ at $3 \mathrm{GPa}$, but $<50^{\circ} \mathrm{C}$ at $5 \mathrm{GPa}$ (Fig. 1; SFigs. 3-6; STable 2). As quartz/ coesite is melted out, the melt fraction increases, the $\mathrm{Mg}^{\#}[100 \times \mathrm{Mg} /$ $(\mathrm{Mg}+\Sigma \mathrm{Fe})]$ of garnet and clinopyroxene increases, and the melt compositions move along garnet-clinopyroxene cotectics, becoming progressively less siliceous and less sodic (Fig. 1; SFigs. 3-9; STables 2 $\& 3$ ). The clinopyroxene/garnet ratio of the residues decreases with increasing melt fraction until clinopyroxene is exhausted, leaving garnet as the sole liquidus phase (Fig. 1a; SFig. 4; STable 2).

Residual garnet and clinopyroxene solid solutions are similar to those from other experimental studies of quartz/coesite-eclogite $\mathrm{e}^{12-16}$ (SFigs. 6-9; SNotes). Significantly, clinopyroxene contains a substantial Ca-eskolaite component as a consequence of reaction between excess $\mathrm{SiO}_{2}$ (quartz/coesite, or $\mathrm{SiO}_{2}$-rich melt) and Ca-Tschermaks solid solution in clinopyroxene $\mathrm{e}^{12-17}$ (Fig. 2; SFig. 9; STable 4; reaction $1)$.

$$
2 \mathrm{Ca}_{0.5}\left[\square_{0.5} \mathrm{AlSi}_{2} \mathrm{O}_{6}=\mathrm{CaAlAlSiO}_{6}+3 \mathrm{SiO}_{2}\right.
$$

$$
\mathrm{Ca}-\text { eskolaite }=\mathrm{Ca}-\text { tschermaks }+ \text { melt } / \text { quartz } / \text { coesite, }
$$

where “ $\square$ " represents a vacancy on the M2-site. 


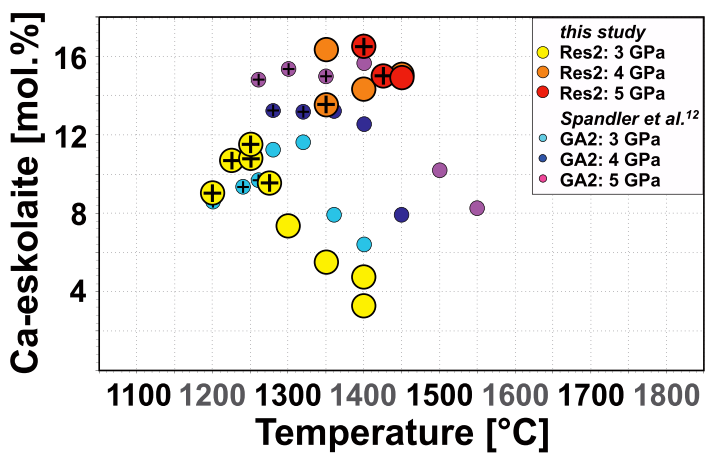

Figure $2 \mid$ Ca-eskolaite component in experimentally crystallised clinopyroxene from Res2 and GA2 as a function of pressure and temperature. The symbol ' + ' indicates the presence of quartz/coesite as residual phase. At a given pressure, both below and above quartz/coesite out, Ca-eskolaite first increases and then decreases with increasing temperature. Although melting residues of Res2 lose siliceous melt fractions and become increasingly depleted in Ca-eskolaite, they still retain their $\mathrm{SiO}_{2}$-saturated character (as will their resulting melt fractions), and are not exhausted in Ca-eskolaite during continuous melt extraction on adiabatic ascent (this Fig., SFig. 6; STable 3). Thus, in contrast to previous predictions ${ }^{20}$, melting residues of initial coesite/quartz-bearing or bimineralic eclogite with Ca-Eskolaite component in clinopyroxene present never become $\mathrm{SiO}_{2}$-deficient (in terms of high pressure normative components) along adiabatic paths, and remain on the $\mathrm{SiO}_{2}$-excess side of the thermal divide in SFig. 6.

The high temperature decrease in Ca-eskolaite (Fig. 2) corresponds to a decrease of silica activity towards higher temperature as soon as quartz/coesite is melted out, driving reaction 1 to the right. However, as long as the activity of silica is unity, i.e. as long as quartz/ coesite is present, this reaction will move to the left.

The increased Ca-eskolaite component in clinopyroxene at greater mantle depths causes melting to occur over a much smaller temperature interval in association with coesite at $5 \mathrm{GPa}$ than with quartz at $3 \mathrm{GPa}$ (Figs. 1 \& 2; SFig. 4). In addition, towards higher pressures the grossular component in garnet and the jadeite component in clinopyroxene are stabilized, whereas the Ca-Tschermaks (Ca-Al-rich) component and the Al-buffonite (Ti-rich) component of clinopyroxene are destabilized (SFigs. 7-9).

During upwelling of heterogeneous mantle along an adiabatic path, residual eclogite Res2 starts to melt at much higher pressure than surrounding 'dry' peridotite, as has been also suggested for other nominally anhydrous eclogite compositions $s^{8,10,12-14,18,19}$ (Fig. 1b). Taking the potential temperature $\left(\mathrm{T}_{\mathrm{p}}\right)$ of the upwelling mantle to be $1360^{\circ} \mathrm{C}$, incipient melting of Res 2 begins at $5 \mathrm{GPa}$ $\left(\sim 160 \mathrm{~km}\right.$ depths) at $1410 \pm 15^{\circ} \mathrm{C}$ (Fig. 1b), consistent within experimental error with derivation of the Res 2 composition by extraction of $\sim 15 \%$ melt from GA2 at $1380^{\circ} \mathrm{C}$ at $5 \mathrm{GPa}$. The relative slopes $(\mathrm{dT} / \mathrm{dP})$ of the adiabat and the Res2 solidus $(\mathrm{dT} / \mathrm{dP}=\sim 30$ $40^{\circ} \mathrm{C} / \mathrm{GPa}$ from 5 to $4 \mathrm{GPa}$, and $\mathrm{dT} / \mathrm{dP}=\sim 160-170^{\circ} \mathrm{C} / \mathrm{GPa}$ from 4 to $3 \mathrm{GPa}$ ) ensure that adiabatic upwelling of Res2 leads to a selffluxing, continuous melting process (Fig. 1b). This is because adiabatic ascent of Res 2 from $\sim 160$ to $\sim 120 \mathrm{~km}$ depths ( 5 to $4 \mathrm{GPa}$ ) results in the continuous breakdown of Ca-eskolaite solid solution in clinopyroxene, causing exsolution of $\mathrm{SiO}_{2}$ as both coesite and $\mathrm{SiO}_{2}$ rich melt fractions, and relative increase of Ca-tschermakite solid solution in residual clinopyroxene (reaction 1; Figs. 1 \& 2; SFigs. 8 \& 9; STable 3). Consequently the solidus and melt compositions remain at the garnet + clinopyroxene + coesite eutectic-like field with continuous production of highly siliceous, incipient melt fractions (reaction 1; Figs. 1 \& 2; SFigs. 5 \& 6).

This distinctive style of self-fluxed, eutectic-like melting rapidly increases during further adiabatic ascent of Res 2 from $\sim 120$ to

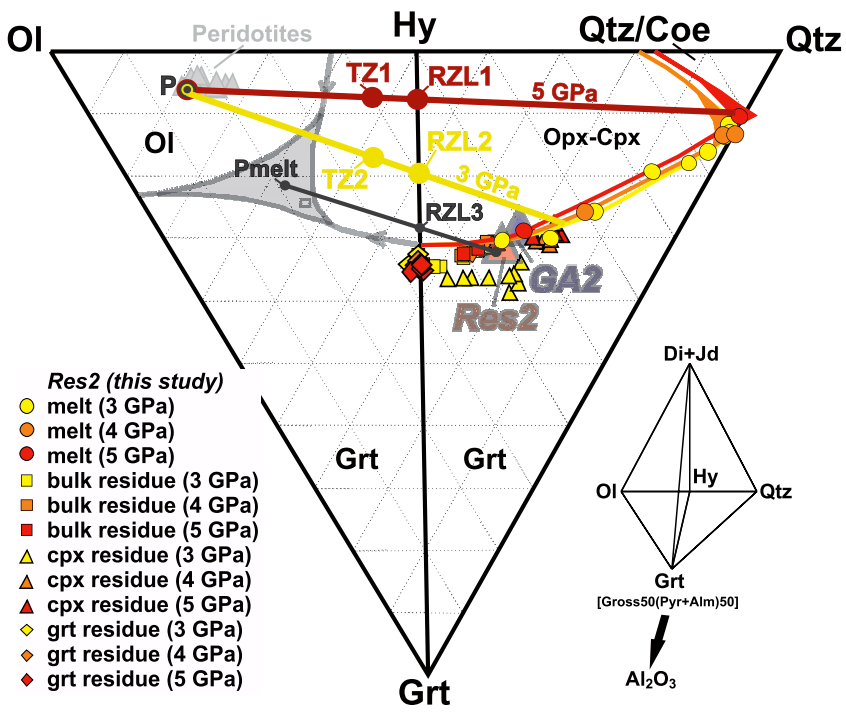

Figure 3 Hybridisation reactions between eclogitic Res2 partial melts and peridotite in the pseudo-ternary Ol-Qtz-Grt diagram projected from (Di + Jd). Dark red and dark yellow lines illustrate normative compositions of "reaction-zone lithologies" (RZL) formed by reaction between peridotite and incipient, highly siliceous (dacitic) and higher degree, less siliceous (andesitic to basaltic) Res2 melts at 5 GPa (RZL1) and $3 \mathrm{GPa}$ (RZL2), respectively. This leads to a higher normative garnet/ orthopyroxene ratio and more $\mathrm{Cr}$-rich clinopyroxene in RZL2, as $3 \mathrm{GPa}$ Res2 melts are less siliceous and more sodic than 5 GPa Res2 melts (see text; SFigs. 5-6, 10; reactions 1-2; reactions 1-3 in SNotes). The compositional variations within the orthopyroxene RZLs formed at different pressures along an adiabat lie on the Hy-Grt thermal divide and lead to corresponding compositional variations in the transition zone layers (TZ1 and TZ2, i.e. the olivine orthopyroxenite/garnet websterite boundaries that mark the silica-undersaturated reaction zone boundaries between peridotite [harzburgite/lherzolite] and the orthopyroxene-rich RZLs). The resulting melt-depleted residual eclogite zones vary considerably in composition over the pressure and temperature range of interest. The dark grey line expresses the hybridisation reaction of incipient melts of peridotite $\left(+\mathrm{H}_{2} \mathrm{O}\right)$ with solid 'dry' residual eclogite Res2. This join Grt-Hy represents a thermal divide of garnet-pyroxene ${ }^{13}$. Ol, olivine; Qtz, quartz; Coe, coesite; Grt, garnet; Hy, hypersthene; Di, diospide; Jd, jadeite; ss, solid solution; $\mathrm{P}$, peridotite; $\mathrm{M}$, eclogitic melt; RZL, orthopyroxene-rich reaction zone layer; TZ, transition zone layer (i.e. the contact between peridotite and orthopyroxene-rich RZL).

$\sim 90 \mathrm{~km}$ (4 to $3 \mathrm{GPa}$ ), due to the sharp increase in exsolution of coesite/quartz from Ca-eskolaite-bearing clinopyroxene, which causes steepening of the Res 2 solidus slope, enhancing melt production (Figs. 1 \& 2; SFig. 4). Melting at $3 \mathrm{GPa}$ therefore occurs at lower temperature and yields much higher fractions of less siliceous melt than at deeper mantle levels (5-4 GPa) along the adiabatic path ( $\sim 5-10 \%$ at $4 \mathrm{GPa}$ to $\sim 35 \%$ at $3 \mathrm{GPa}$ ) (Fig. 1; SFigs. $4-6$ ).

The destabilisation of Ca-Eskolaite, jadeite, and grossular but stabilisation of Ca-Tschermaks and Al-buffonite during mantle upwelling causes decreased partitioning of $\mathrm{Na}$ and $\mathrm{Al}$ but increased partitioning of $\mathrm{Ca}$ and $\mathrm{Ti}$ into clinopyroxene and decreased partitioning of $\mathrm{Ca}$ into garnet relative to melt (SFigs. 7-10; STable 3). Higher Res2 melt fractions $(>15-20 \%)$ formed at $3 \mathrm{GPa}$ are therefore more sodic and aluminous, but less siliceous and titanifereous than incipient Res2 melts formed at 4-5 GPa along the chosen adiabat (Fig. 1; SFigs. $5 \& 6$ ). Consequently, as the residues of Res2 melting at $3 \mathrm{GPa}$ lose $\sim 15$ to $\leq 35 \%$ melt, they become bimineralic eclogite (residual garnet and clinopyroxene only) with relatively high $\mathrm{Mg}^{\#}$. Clinopyroxene is characterised by high Ca-tschermaks and diopside, and relatively low Ca-eskolaite and jadeite components, 
relative to clinopyroxene from coesite-eclogite residues of Res 2 melting at 5-4 GPa with $\leq 5 \%$ melt loss during adiabatic upwelling (Fig. 2; SFigs. 8-9; STable 3). Residual garnet at $3 \mathrm{GPa}$ has a higher pyrope and lower almandine and grossular components with respect to residual garnet at $5 \mathrm{GPa}$ (SFig. 7).

During adiabatic upwelling of heterogeneous mantle from 5 to $3 \mathrm{GPa}$, ambient peridotitic mantle will be metasomatised by (highly) siliceous melt fractions continuously extracted from Res2 eclogite. These melt fractions will react with peridotite mineral phases (mainly olivine but also pyroxene and garnet), and thus, freeze into the ambient mantle, producing an orthopyroxene-rich reaction zone layer (RZL) with garnet and minor clinopyroxene lying on the thermal divide ${ }^{13}$ (Fig. 3; reaction 2; reactions $1-3$ in SNotes). Mineral compositions and proportions of the newly formed RZL's will reflect some admixtures of peridotite and varying siliceous and sodic melt compositions produced by continuous melting of Res 2 during adiabatic ascent (Fig. 3). This process therefore adds eclogite derived incompatible elements back into an ambient (depleted) peridotite mantle. As the extracted melt compositions vary, metasomatic effects will also vary along the adiabatic path (Figs. $1 \& 3$ ).

The behaviour of $\mathrm{Na}_{2} \mathrm{O}$ and $\mathrm{Cr}_{2} \mathrm{O}_{3}$ are potentially useful in discerning the effects of melting and reaction in heterogeneous eclogite/ peridotite lithologies. $\mathrm{Cr}_{2} \mathrm{O}_{3}$ is refractory with respect to eclogitic melts. The $\mathrm{Cr} / \mathrm{Al}$ of oceanic crust is relatively low $\left(<0.01^{12,17,20}\right)$. Residual garnet and clinopyroxene remain low in $\mathrm{Cr}_{2} \mathrm{O}_{3}$ and $\mathrm{Cr} / \mathrm{Al}$ even after extraction of high melt fractions from residual eclogite $^{12,17,20} . \mathrm{Cr} / \mathrm{Al}$ in fertile lherzolite is much higher and increases in residues from partial melting ${ }^{21}$, so highly refractory harzburgite residues have the highest $\mathrm{Cr} / \mathrm{Al}$ ratios and $\mathrm{Mg}^{\#} \mathrm{~s}^{21}$. In contrast, $\mathrm{Na}_{2} \mathrm{O}$ and $\mathrm{Al}_{2} \mathrm{O}_{3}$ are mobile in eclogitic partial melts (GA2 and Res2) but are controlled by partitioning relationships with clinopyroxene in residual eclogite (SFigs. 5 \& 10; STable 3). High \% Res2 melt fractions at $3 \mathrm{GPa}$ are more enriched in $\mathrm{Na}_{2} \mathrm{O}$ than $5 \mathrm{GPa}$ incipient melts (SFig. 5) and are most effective in leaching $\mathrm{Cr}^{3+}$ and $\mathrm{Fe}^{3+}$ from garnet of adjacent peridotite (or reacting with chromite of adjacent harzburgite or dunite), relative to Res2 low-degree melts formed at $5 \mathrm{GPa}$. Therefore, reaction between eclogitic melts and peridotitic mantle at relatively low pressure (e.g. $3 \mathrm{GPa}$ ) is more effective than at high pressure (e.g. $5 \mathrm{GPa}$ ) at forming $\mathrm{Na}$-Cr-rich (and $\mathrm{Na}-\mathrm{Fe}^{3+}$-rich) pyroxene such as kosmochlor (and acmite) in the RZL according to reaction 2 (and reaction 3 in SNotes).

$$
\begin{gathered}
(\mathrm{Ca}, \mathrm{Mg})_{3}\left(\mathrm{Cr}, \mathrm{Fe}^{3+}\right)_{2} \mathrm{Si}_{3} \mathrm{O}_{12}+2 \mathrm{NaAlSi}_{2} \mathrm{O}_{6}= \\
2 \mathrm{Na}\left(\mathrm{Cr}, \mathrm{Fe}^{3+}\right) \mathrm{Si}_{2} \mathrm{O}_{6}+(\mathrm{Ca}, \mathrm{Mg})_{3} \mathrm{Al}_{2} \mathrm{Si}_{3} \mathrm{O}_{12} \\
\mathrm{Cr}-\mathrm{Fe}^{3+} \text { garnet (peridotite) }+ \text { jadeite (eclogitic melt) } \\
=\text { kosmochlor, acmite (RZL) + grossular (RZL). }
\end{gathered}
$$

Reports of $\mathrm{Na}+\mathrm{Cr}$-rich pyroxene at the contacts between refractory eclogite layers in peridotite in peridotite-pyroxenite massifs ${ }^{22}$, as well as frequently observed 'eclogitic' garnets containing little or no $\mathrm{Cr}$ and $\mathrm{Na}$ included in some diamonds ${ }^{23}$, may form via metasomatic processes rather than extensive melt depletion of peridotite, or garnets crystallised from mafic (i.e. eclogitic) lithologies, respectively $y^{22,23}$ (see also below).

Assuming a Res 2 bulk $\mathrm{H}_{2} \mathrm{O}$ content of $\sim 0.26$ wt.\%, Res 2 melt fractions will release considerable $\mathrm{H}_{2} \mathrm{O}$ during adiabatic upwelling (a maximum of 4 wt.\% $\mathrm{H}_{2} \mathrm{O}$ in melt at $5 \mathrm{GPa}$ for a $5 \%$ melt; $\sim 0.5$ wt. $\% \mathrm{H}_{2} \mathrm{O}$ in melt at $3 \mathrm{GPa}$ for a $40 \%$ melt). This results mainly from the preferential partitioning of $\mathrm{H}_{2} \mathrm{O}$ into the melt phase over NAMs in (residual) eclogite ${ }^{1,2,4}$. As these hydrous melts react with enclosing peridotite, $\mathrm{H}_{2} \mathrm{O}$ will be in part be incorporated into NAMs in the newly formed orthopyroxene-rich RZLs. However, an orthopyroxene-rich RZL containing $75 \%$ orthopyroxene, $20 \%$ garnet, and
$5 \%$ clinopyroxene may only be able to accommodate $\sim 0.03 \mathrm{wt} . \%$ of $\mathrm{H}_{2} \mathrm{O}$ (i.e. assuming that orthopyroxene, garnet and clinopyroxene take up maxima of $\sim 320 \mathrm{ppm}_{2} \mathrm{O}, \sim 200 \mathrm{ppm} \mathrm{H}_{2} \mathrm{O}$ and $\sim 980 \mathrm{ppm}$ $\mathrm{H}_{2} \mathrm{O}$ respectively under water-saturated conditions ${ }^{4,24}$ ), which means the excess $\mathrm{H}_{2} \mathrm{O}$ may be present as vapour and thus lower the solidi of the orthopyroxene-rich RZL and adjacent mantle lithologies. New melting may then initiate in the orthopyroxene-rich RZL, or olivine orthopyroxenite/websterite formed at the contact between peridotite and orthopyroxene-rich RZL ${ }^{13}$, or continue in the residual eclogite, i.e. depending on the solidus of the particular mantle lithology + $\mathrm{H}_{2} \mathrm{O}$ and $\mathrm{T}_{\mathrm{p}}$ (Fig. 3).

Reaction and freezing processes may initially only occur at the eclogite-peridotite boundary for incipient Res 2 melts at $5 \mathrm{GPa}$ as segregation of melt from the eclogitic residue will be limited by poor interconnection of melt networks/pools (SFig. 3). In contrast, higher Res2 melt fractions at $3 \mathrm{GPa}$ must separate from residual eclogite, as intergranular melt will be strongly interconnected at $\sim 30 \%$ melting (SFig. 3). It is conceivable that an original eclogite body (such as Res2) could become strongly zoned during adiabatic ascent due to reaction at the eclogite/peridotite interface. The core of such bodies may comprise a solid residue of Res2 (RRes2) with a higher solidus temperature than Res2, with or without partial melt. Provided that the solidus temperature of the RZL remains above ambient mantle conditions, it may act as a seal to prevent further melt migration and reaction with the surrounding peridotite. In this case, eclogitic partial melts produced by continued adiabatic upwelling will be retained in the eclogite, so that melt and the solid residue remain in equilibrium. Convective motions are likely to cause stirring, stretching and internal deformation of Res 2 zoned fragments. Eclogitic bodies may be deformed into layers, even at the $\mathrm{cm}$-scale ${ }^{18}$, increasing the reaction surface, leading to opening of the sealing RZL and RRes2 layers, and release of Res 2 melt, which freezes into adjacent peridotite on contacts. Continuous mantle convection and stirring may repeatedly re-open and re-seal such rheologically contrasting, refertilised Res 2 melt bodies until all melt available has reacted into peridotite, ensuring a wide distribution of frozen 'crustal components' within the Earth's upper mantle.

Residual bimineralic eclogite formed at $3 \mathrm{GPa}$ may become sufficiently Mg-rich and clinopyroxene low in both Ca-eskolaite and jadeite components (Fig. 2; SFig. 7-9) that solidus temperatures are no longer below those of (refertilized) harzburgite/lherzolite, olivine orthopyroxenite/websterite (i.e. the contact between peridotite and orthopyroxene-rich RZL), or orthopyroxenite (RZL) lithologies (Fig. 3). Subsequent melting will then proceed at the melting minimum of olivine orthopyroxenite/websterite $\pm \mathrm{H}_{2} \mathrm{O}^{13}$ (TZ in Fig. 3). Melt compositions produced will be nepheline-normative, lying to the silica-undersaturated side of the thermal divide ${ }^{13,19,25}$ in Fig. 3. Due to the relatively high $\mathrm{Na} / \mathrm{Ca}$ and low $\mathrm{Ca} / \mathrm{Al}$ ratios of the refertilising eclogitic (Res2) melts (SFig. 5), these new melts will also be characterised by higher $\mathrm{Na} / \mathrm{Ca}$ and lower $\mathrm{Ca} / \mathrm{Al}$ ratios ('crustal signature') relative to melt compositions known from nephelinenormative melts of 'pristine' peridotite ${ }^{10,26}$.

Subduction and subsequent upwelling of residual eclogite Res2 enclosed in ambient mantle may continuously cause numerous other heterogeneities (Fig. 3). For instance, reduced mantle at high pressures ${ }^{27}$ may impose its low oxygen fugacity $\left(\mathrm{fO}_{2}\right)$ on widely distributed bodies of Res2, assuming that recycled crustal material is predominantly oxidized ${ }^{28}$. This may cause oxidation of $\mathrm{CH}_{4}$ present in reduced ambient mantle to form $\mathrm{H}_{2} \mathrm{O}$ and $\mathrm{C}$ (graphite/diamond), and instigate redox melting (reaction 4 in SNotes) ${ }^{26,28,29}$.

As the adiabat under consideration lies in the (incipient) melting field of peridotite $+\mathrm{H}_{2} \mathrm{O}$ under oxidising conditions (Fig. 1b), the presence of significant $\mathrm{H}_{2} \mathrm{O}$ may also lead to (incipient) melting of peridotite ${ }^{30}$. The resulting melts are olivine-rich basanite to nephelinite, enriched in alkalis, with high $\mathrm{Ca} / \mathrm{Al}$ and $\mathrm{Mg}^{\#} \sim 70-75$. Reaction of these melts with eclogite such as Res2, will increase the 
modal clinopyroxene content and jadeite components (with possibly slightly higher kosmochlor solid solution) as well as decrease the Caeskolaite component of clinopyroxene with little or no change in $\mathrm{Mg}^{*}$ or $\mathrm{Cr} / \mathrm{Al}$ of the eclogite. Clinopyroxene enriched zones will be produced at the peridotite/eclogite interface by such 'back-reaction' varying from possible olivine-bearing garnet pyroxenite with little or no orthopyroxene and $\mathrm{Mg}^{*} \sim 85-90$ (metasomatised peridotite) to garnet-bearing clinopyroxenite with $\mathrm{Mg}^{*} \sim 75-80$ and less orthopyroxene (metasomatised eclogite) than in the analogous reaction of siliceous eclogitic melt into peridotite (Fig. 3).

Under oxidising conditions, the presence of significant $\mathrm{H}_{2} \mathrm{O}$ may also lead to melting of peridotite $+\mathrm{CO}_{2}+\mathrm{H}_{2} \mathrm{O}$ at greater mantle depths than Res2 along the given adiabat (Fig. 1b). Resulting melts are carbonatitic to carbonate-bearing silicate melts ${ }^{26,29,31,32}$. If residual eclogite Res2 is swamped by such melts, it will react to form new clinopyroxene-rich RZL (with increased diopside and CaTschermaks solid solution, and reduced or no Ca-Eskolaite component) in the presence of $\mathrm{C}$ (graphite/diamond) and/or carbonate and/ or $\mathrm{CO}_{2}$ and/or $\mathrm{SiO}_{2}$ (reactions 3-4; Fig. 3; SFig. 11).

$$
\begin{aligned}
& 2 \mathrm{Ca}_{0.5}\left[\boldsymbol{\square}_{0.5} \mathrm{AlSi}_{2} \mathrm{O}_{6}+\mathrm{CaMg}\left(\mathrm{CO}_{3}\right)_{2}=\right. \\
& \mathrm{CaMgSi}_{2} \mathrm{O}_{6}+\mathrm{CaAlAlSiO}_{6}+\mathrm{SiO}_{2}+2 \mathrm{C}+2 \mathrm{O}_{2}
\end{aligned}
$$

$$
\begin{aligned}
& \mathrm{Ca} \text { - eskolaite (eclogite) } \\
& + \text { dolomite (carbonatitic to carbonate-bearing silicate melts) } \\
& =\text { diopside }(\mathrm{RZL})+\mathrm{Ca} \text {-tschermaks }(\mathrm{RZL}) \\
& +\mathrm{SiO}_{2} \text { (melt/quartz/coesite; RZL) } \\
& + \text { graphite/diamond } / \mathrm{CO}_{2} \text { (melt/vapour)(RZL) } \\
& 2 \mathrm{Ca}_{0.5}[]_{0.5} \mathrm{AlSi}_{2} \mathrm{O}_{6}+\mathrm{MgCO}_{3}+= \\
& \mathrm{Mg}_{2} \mathrm{Si}_{2} \mathrm{O}_{6}+\mathrm{CaAlAlSiO}+\mathrm{SiO}_{2}+2 \mathrm{C}+2 \mathrm{O}_{2}
\end{aligned}
$$

Thus, reaction with carbonate-rich melts may also cause melting of Res2, producing (sodic) carbonate-bearing silicate or silicatebearing carbonatitic melts (as observed previously ${ }^{33,34}$ ), buffered by these reactions. Subsequent reactions of eclogitic carbonate melts with ambient mantle may in turn leach out $\mathrm{Cr}$ and $\mathrm{Na}$ from peridotitic garnet, possibly producing $\mathrm{Cr}$ - and Na-poor garnets enclosed in some diamonds (reactions 5-6 in SNotes), as described above (reaction 2; and reaction 3 in SNotes).

Redox melting and -freezing may thus lead to the co-existence of carbonate- and/or diamond-bearing peridotite and eclogite depending on the pressure, temperature and $\mathrm{fO}_{2}$ conditions relative to silicacarbonate-diamond redox equilibrium reactions ${ }^{26,29,35-37}$ (reactions $3-4$; reactions $4-8$ in SNotes). However, there is currently a lack of experimental calibration of these reactions with respect to parameters of pressure, temperature, $\mathrm{fO}_{2}$, and composition.

Dynamic mantle processes ensure continuous changes in redox conditions at the interface between eclogites and peridotite, suggesting continuous formation and destruction of diamond and carbonatite along an adiabat. Subduction and recycling of former crust appears to be one of the main causes for continuous but episodic self-driven and -fluxing (redox-) re-melting and -freezing events.
Thus, it is not surprising that (incipient) melting and alkaline magmatism occurs episodically and with increased frequency over the Earth's history after commencement of tectonic regimes involving plate subduction ${ }^{38-40}$.

\section{Methods}

Res2 starting composition was prepared as glassed synthetic sintered oxide powders using established procedures ${ }^{13}$, and doped with a trace-element blend of 10 elements ( $\mathrm{La}, \mathrm{Ce}, \mathrm{Sm}, \mathrm{Gd}, \mathrm{Yb}, \mathrm{Sc}, \mathrm{Y}, \mathrm{Zr}, \mathrm{Sr}, \mathrm{Cu}$ ) at levels of $400 \mathrm{ppm}$. We used established experimental and analytical procedures as outlined by Spandler et al. ${ }^{12}$. The accuracy of the EDS/SEM methods employed has been demonstrated by Spandler et al. ${ }^{41}$. Sample preparation, FTIR spectroscopy, and quantification of $\mathrm{H}_{2} \mathrm{O}$ and $\mathrm{CO}_{2}$ in Res2_19 melts were similar to Liu et al. ${ }^{42}$ and Mandeville et al. ${ }^{43}$. Sample thickness was on average $200 \mu \mathrm{m}$. FTIR data, absorbance values, and typical FTIR spectra are given in SFig. 2 and STable 2. Absorbance peaks at $\sim 3550 \mathrm{~cm}^{-1}$ is attributed to $\mathrm{O}-\mathrm{H}$ stretching modes of $\mathrm{H}_{2} \mathrm{O}$ and $\mathrm{OH}$. To determine the $\mathrm{H}_{2} \mathrm{O}$ content of the sample, the backgrounds of the corresponding bands were estimated and subtracted from the absorbance by interpolation of a straight line through the minima at the high and low wave-number ends of the absorption peaks. The minute absorbance peak at

$\sim 2950 \mathrm{~cm}^{-1}$ represents tiny amounts of organic contamination, and hence, is not further considered.

1. Aubaud, C., Hirschmann, M. M., Withers, A. C. \& Hervig, R. L. Hydrogen partitioning between melt, clinopyroxene, and garnet at $3 \mathrm{GPa}$ in a hydrous MORB with 6 wt.\% $\mathrm{H}_{2}$ O. Contrib. Mineral. Petrol. 156, 607-625 (2008).

2. Hauri, E. H., Gaetani, G. A. \& Green, T. H. Partitioning of water during melting of the Earth's upper mantle at $\mathrm{H}_{2} \mathrm{O}$-undersaturated conditions. Earth Planet. Sci. Lett. 248, 715-734 (2006).

3. Katayama, I., Nakashima, S. \& Yurimoto, H. Water content in natural eclogite and implication for water transport into the deep upper mantle. Lithos 86, 245-259 (2006).

4. Rosenthal, A. et al. Experimental determination of carbon partitioning between upper mantle minerals and silicate melts: initial results and comparison to trace element partitioning ( $\mathrm{Nb}, \mathrm{Rb}, \mathrm{Ba}, \mathrm{U}, \mathrm{Th}, \mathrm{K})$. Paper presented at American Geophysical Union (AGU): DI13B Redox Controls and C-O-H Equilibria in the Earth's Interior, San Francisco, USA. Fall Meeting Abstracts: 1, 2429. (2012, 12, 3-7).

5. Schmidt, M. W. \& Poli, S. Experimentally based water budgets for dehydrating slabs and consequences for arc magma generation. Earth Planet. Sci. Lett. 163, 361-379 (1998).

6. Kennett, B. L. N. \& Hilst, V. D. [Seismic Structure of the Mantle: From Subduction Zone to Craton] The Earth's mantle [Jackson, I. (ed.)] [381-404] (Cambridge University Press, Cambridge, 1998).

7. van Mierlo, W. L., Langenfrost, F., Frost, D. J. \& Rubie, D. C. Stagnation of subducting slabs in the transition zone due to slow diffusion in majoritic garnet. Nature Geoscience 6, 400-403 (2013).

8. Hirschmann, M. M. \& Stolper, E. A possible role for garnet pyroxenite in the origin of the "garnet signature" in MORB. Contrib. Mineral. Petrol. 124, 185-208 (1996).

9. Hofmann, A. W. [Sampling Mantle Heterogeneity through Oceanic Basalts: Isotopes and Trace Elements] The mantle and core [Carlson, R. W. (ed.)] [61-101] (Elsevier, Amsterdam, 2003).

10. Mallik, A. \& Dasgupta, R. Reaction between MORB-eclogite derived melts and fertile peridotite and generation of ocean island basalts. Earth Planet. Sci. Lett. 329-330, 97-108 (2012).

11. Sobolev, A. V. et al. The amount of recycled crust in sources of mantle-derived melts. Science 316, 412-417 (2007).

12. Spandler, C., Yaxley, G. M., Green, D. H. \& Rosenthal, A. Phase Relations and Melting of Anhydrous K-bearing Eclogite from 1200 to $1600^{\circ} \mathrm{C}$ and 3 to $5 \mathrm{GPa}$. J. Petrol. 49, 771-795 (2008).

13. Yaxley, G. \& Green, D. H. Reactions between eclogite and peridotite: mantle refertilisation by subduction of oceanic crust. Schweiz. Mineral. Petrogr. Mitt. 78, 243-255 (1998).

14. Pertermann, M. \& Hirschmann, M. M. Anhydrous partial melting experiments on MORB-like eclogite: Phase relations, phase compositions and mineral-melt partitioning of major elements at 2-3 GPa. J. Petrol. 44, 2173-2201 (2003).

15. Yaxley, G. M. \& Sobolev, A. V. High-pressure partial melting of gabbro and its role in the Hawaiian magma source. Contrib. Mineral. Petrol. 154, 371-383 (2007).

16. Klemme, S., Blundy, J. D. \& Wood, B. J. Experimental constraints on major and trace element partitioning during partial melting of eclogite. Geochim. Cosmchim. Acta 66, 3109-3123 (2002).

17. Pertermann, M. \& Hirschmann, M. M. Trace-element partitioning between vacancy-rich eclogitic clinopyroxene and silicate melt. Am. Mineral. 87, 1365-1376 (2002).

18. Kogiso, T., Hirschmann, M. M. \& Pertermann, M. High-pressure melting of mafic lithologies in the mantle. J. Petrol. 45, 2407-2422 (2004).

19. Yaxley, G. M. Experimental study of the phase and melting relations of homogeneous basalt + peridotite mixtures and implications for the petrogenesis of flood basalts. Contrib. Mineral. Petrol. 139, 326-338 (2000). 
20. Kogiso, T. \& Hirschmann, M. M. Partial melting experiments of bimineralic eclogite and the role of recycled mafic oceanic crust in the genesis of ocean island basalts. Earth Planet. Sci. Lett. 249, 188-199 (2006).

21. Walter, M. Melting of garnet peridotite and the origin of komatiite and depleted lithosphere. J. Petrol. 39, 29-60 (1998).

22. Rosenthal, A. et al. New insights into the genesis of peridotite-pyroxenite layers: Western Gneiss Region, Norway. Paper presented at $9^{\text {th }}$ Int. Kimberlite Conf.: 9IKC-03 Mantle Petrology and geochemistry, Johann Wolfgang Geothe University, Frankfurt, Germany. Extended Abstract: 9IKC-A-00201. (2008, 08, 10-15).

23. Kiseeva, E. S. et al. Metapyroxenite in the mantle transition zone revealed from majorite inclusions in diamonds. Geology 41, 883-886 (2013).

24. Kovács, I. et al. An experimental study of water in nominally anhydrous minerals in the upper mantle near the water saturated solidus. J. Petrol. 53, 2067-2093 (2012).

25. Kogiso, T., Hirose, K. \& Takahashi, E. Melting experiments on homogeneous mixtures of peridotite and basalt: application to the genesis of ocean island basalts. Earth Planet. Sci. Lett. 162, 45-61 (1998).

26. Green, D. H. \& Falloon, T. J. [Primary magmas at mid-ocean ridges, "hotspots," and other intraplate settings: Constraints on mantle potential temperature] Plates, plumes, and paradigms [Foulger, G. R., Natland, J. H., Presnall, D. C. \& Anderson, D. L. (eds.)] [217-247] (Geol. Soc. Am., Special Paper 388 2005).

27. Frost, D. J. \& McCammon, C. A. The redox state of Earth's mantle. Annual Review Earth Planet. Sci. 36, 389-420 (2008).

28. Foley, S. F. A Reappraisal of Redox Melting in the Earth's Mantle as a Function of Tectonic Setting and Time. J. Petrol. 52, 1363-1391 (2011).

29. Green, D. H. \& Falloon, T. J. [Pyrolite: a Ringwood concept and its current expression] The Earth's mantle [Jackson, I. (ed.)] [311-378] (Cambridge University Press, Cambridge, 1998)

30. Green, D. H., Hibberson, W. O., Kovács, I. \& Rosenthal, A. Water and its influence on the lithosphere - asthenosphere boundary. Nature 467, 448-451 (2010).

31. Brey, G. P., Bulatov, V. K. \& Girnis, A. V. Influence of water and fluorine on melting of carbonated peridotite at 6 and 10 GPa. Lithos 112(S1), 249-259 (2009).

32. Foley, S. F. et al. The composition of near-solidus melts of peridotite in the presence of $\mathrm{CO}_{2}$ and $\mathrm{H}_{2} \mathrm{O}$ between 40 and 60 kbar. Lithos 112, Part 1 Sp. Iss. S1, 274-283 (2009).

33. Dasgupta, R. et al. Carbon-dioxide-rich silicate melt in the Earth's upper mantle. Nature 493, 211-215 (2013).

34. Kiseeva, E. S. et al. An Experimental Study of Carbonated Eclogite at 3.5-5.5 GPa - Implications for Silicate and Carbonate Metasomatism in the Cratonic Mantle. J. Petrol. 53, 727-759 (2012).

35. Eggler, D. H. \& Baker, D. R. [Reduced volatiles in the system C-O-H: implications to mantle melting, fluid formation, and diamond genesis] High-Pressure Research in Geophysics [Akimoto, S. \& Manghnani, M. H. (eds.)] [237-250] (Center for Academic Publications, Tokyo, 1982).

36. Luth, R. W. Diamonds, Eclogites, and the Oxidation State of the Earth's Mantle. Science 261, 66-68 (1993).

37. Stagno, V., Oiwang, D. O., McCammon, C. A. \& Frost, D. J. The oxidation state of the mantle and the extraction of carbon from Earth's interior. Nature 493, 84-88 (2013).

38. Foley, S. F. The genesis of continental basic alkaline magmas: an interpretation in terms of redox melting. J. Petrol. Sp. Lithophere Issue, 139-161 (1988).

39. Jelsma, H., Barnett, W. Richards, S. \& Lister, G. Tectonic setting of kimberlites. Lithos 112, 155-165 (2009).

40. Kogarko, L. N. Alkaline magmatism and enriched mantle reservoirs: Mechanisms, time, and depth of formation. Geochem. Internat. 44, 3-10 (2006)

41. Spandler, C., Yaxley, G. M., Green, D. H. \& Scott, D. Experimental phase and melting relations of metapelite in the upper mantle: implications for the petrogenesis of intraplate magmas. Contrib. Mineral. Petrol. 160, 569-589 (2010).
42. Liu, X., O'Neill, H. St . C. \& Berry, A. J. The Effects of Small Amounts of $\mathrm{H}_{2} \mathrm{O}, \mathrm{CO}_{2}$ and $\mathrm{Na}_{2} \mathrm{O}$ on the Partial Melting of Spinel Lherzolite in the System CaO-MgO$\mathrm{Al}_{2} \mathrm{O}_{3}-\mathrm{SiO}_{2}-\mathrm{H}_{2} \mathrm{O}-\mathrm{CO}_{2}-\mathrm{Na}_{2} \mathrm{O}$ at $1.1 \mathrm{GPa}$. J. Petrol. 47, 409-434 (2006).

43. Mandeville, C. W. et al. Determination of molar absorptivities for infrared absorption bands of $\mathrm{H}_{2} \mathrm{O}$ in andesitic glasses. Am. Mineral. 87, 813-821 (2002).

44. Bose, K. \& Ganguly, J. Quartz-coesite transition revisited: Reversed experimental determination at $500-1200^{\circ} \mathrm{C}$ and retrieved thermochemical properties. Am. Mineral. 80, 231-238 (1995).

45. Hirschmann, M. M. Mantle solidus: Experimental constraints and the effects of peridotite composition. G-cubed 1, $2000 \mathrm{GC000070} \mathrm{(2000).}$

46. Green, D. H., Falloon, T. J., Eggins, S. M. \& Yaxley, G. M. Primary magmas and mantle temperatures. Europ. J. Mineral. 13, 437-451 (2001).

47. Herzberg, C. et al. Temperatures in ambient mantle and plumes: Constraints from basalts, picrites, and komatiites. G-cubed 8, $2006 \mathrm{GC001390} \mathrm{(2007).}$

48. McKenzie, D. \& Bickle, M. J. The volume and composition of melt generated by extension of the lithosphere. J. Petrol. 29, 625-679 (1988).

\section{Acknowledgments}

We thank Dean Scott, David Clark and Bill Hibberson for support in the high-pressure facilities, and Frank Brink for support at the Centre for Advanced Microscopy at the ANU. This research was supported by an Australian Research Council Discovery Grant to G.M.Y. and D.H.G. A.R. acknowledges funding by an ANU PhD Scholarship, a RSES 2007 joint 'Mervyn \& Katalyn Paterson Fellowship', and a Marie Curie International Incoming Fellowship (302637). I.K. acknowledges funding by an A.E. Ringwood Memorial Scholarship, an Australian International Postgraduate Research Scholarship, a Marie Curie International Reintegration Grant (NAMS-230937), the Bolyai Fellowship Program, and the Hungarian Scientific Research Found (OTKA PD101683)

\section{Author contributions}

The manuscript and the ideas therein were mainly developed by A.R., G.M.Y. and D.H.G., with contributions from all other co-authors. G.M.Y. and D.H.G. initiated and planned the project, which was carried out by A.R. as part of her PhD-project. G.M.Y. and D.H.G. acted as supervisors, and J.H. and C.S. as advisors, and supported A.R. comprehensively during her $\mathrm{PhD}$. A.R. carried out the high pressure experimental work, prepared the experimental charges for SEM analysis, made SEM micro-analyses, compiled all the analyses, formulated results and conclusions as a $\mathrm{PhD}$-thesis, as well as subsequent conclusions such as the new silica-carbonate-diamond redox equilibrium reactions. I.K. supported A.R. substantially in preparing the thin section for FTIR analyses, in performing the FTIR Spectroscopy and in processing of the FTIR data.

\section{Additional information}

Supplementary information accompanies this paper at http://www.nature.com/ scientificreports

Competing financial interests: The authors declare no competing financial interests.

How to cite this article: Rosenthal, A. et al. Continuous eclogite melting and variable refertilisation in upwelling heterogeneous mantle. Sci. Rep. 4, 6099; DOI:10.1038/srep06099 (2014)

This work is licensed under a Creative Commons Attribution-NonCommercialNoDerivs 4.0 International License. The images or other third party material in this article are included in the article's Creative Commons license, unless indicated otherwise in the credit line; if the material is not included under the Creative Commons license, users will need to obtain permission from the license holder in order to reproduce the material. To view a copy of this license, visit http:// creativecommons.org/licenses/by-nc-nd/4.0/ 